\title{
A Sociological Analysis of Education as a Prerequisite for the Process of Development: A Case of Southern Punjab (Pakistan)
}

\author{
Tehmina Sattar \\ Department of Sociology, Bahauddin Zakariya University, Multan (Pakistan) \\ E-Mail: tehminasattar@hotmail.com
}

Accepted: February 17, 2012 Published: April 14, 2012

Doi:10.5296/ijld.v2i2.1628 URL: http://dx.doi.org/10.5296/ijld.v2i2.1628

\begin{abstract}
:
Government of Pakistan has been constantly striving to perk up and stabilize the process of development. One of the major sectors which become the victim of negligence is education sector of Southern Punjab (Pakistan). The significance of education can be judged by the fact that literacy rate is an imperative parameter for Human Development Index (HDI). Education is the most imperative asset for enhancing human abilities and capabilities. At the micro level education is allied with huge income generating opportunities while at the macro level education fabricates skilled labor force and contributes to sustainable development. The new stipulate for increased professionalism on the part of education system is the major determinant of development for Pakistan. But regrettably the education sector of Pakistan is facing many challenges like low budget allocation, lack of accountability, pathetic potential for resource mobilization, poverty, gender discrimination, low quality education and weak policy framework. The researcher assembled the data from N1=600 respondents from affiliated schools of Board of Intermediate and Secondary Education (BISE). Interview schedule was used as a tool for data collection procedure for the purpose of research accomplishment cross sectional survey research design. Thus the researcher found that innovation, broad vision and market awareness are the major prerequisites of education in the contemporary world. Despite this education fabricated a tolerant society (equipped with skilled labor force and innovation process) by crafting new knowledge for the purpose of economic growth and sustainable development.
\end{abstract}

\section{Introduction:}

The significance of literacy can be judged by the fact that literacy rate is an essential parameter for stabilizing the process of sustainable development (Akram and Khan, 2007). Education is the most important asset for the development of any country and its significance is 
noteworthy (Handa, 1999). Education is the central key to the process of development and it plays a momentous role in achieving the Millennium Development Goals and one of the powerful instruments for plummeting poverty and inequality. Education amplifies the socio-political and economic adjustment of an individual in the society (Shami, et al. 2005). Education is of paramount importance to all the sectors whether social, political or economic in nature. Education expansion perks up economic welfare, reduces income inequalities, ensure economic security and bring democratization (Hannuman and Buchmann, 2005).

Education plays a momentous role in the phenomenal advancement of the Western countries like United States, Japan, Korea, Singapore and Thailand. Therefore education is the only tool to make development in the underdeveloped countries like Pakistan by eradicating various social evils (Kennedy and Baxter, 2000). Education is the indispensable human right that endow with various means for development of nations. History has witnessed that no nation has been able to accelerate in terms of development process without considering this aim as prerequisite (Jongbloed, 2004). The importance of education can be judged by the fact that out of eight Millennium Development Goals (MGD's) second goal belongs to education and its target is to achieve the Universal Primary Education (UPE) for all boys and girls by 2015 (Lewin, 2008). The development process of any country depends upon the skills and knowledge of human resources and this is only feasible through the investment in human capital formation through education expansion (Khan, 2003).

"The principal goal of education is to create men who are capable of doing new things, not simply of repeating what other generations have done."

(Jean Piaget (1896-1980) Swiss cognitive psychologist).

Education is always positively narrated with occupational opportunities because increase in education increases the skill development and labor market outcomes (Fasih, 2008). Women with higher education level can take more care of their health and can comprehend the significance of smaller families. Consequently they prefer lower fertility rate for increased living standards. In addition to this educated parents have positive influence on the education of their children (Sathar, et al. 1988). The importance of education can be judged by the fact that education ensures critical and analytical thinking among the people by making them meticulous members of the state (Kingdon, 2007). Education is the most significant asset that empowers the people who are excluded from the decision making process (Rowlands, 1995). Since education is an investment, there is a significant positive correlation between education and economic expansion. When people are educated, their standards of living are likely to improve, since they are empowered to access productive ventures, which will ultimately lead to an improvement in their livelihoods (Aikman and Unterhalter, 2005). The role of education therefore, is not just to impart knowledge and skills that enable the beneficiaries to function as economies and social change agents in society, but also to impart values, ideas, ideologies, attitudes, rationales and aspirations important for the process of development (Anderson and Dexter, 2005). The straightforward linkage between education is through the improvement of labor skills, which in turn increases opportunities for well paid productive employment (Nconco, 2006). This then might enable the citizens of any nation to fully exploit the potential positively. Education is the basic human right that provides the means for development of nations. Education can perks up the process of sustainable development in Pakistan by making 
it tolerant society by crafting new knowledge for the people and brings various economic benefits (World Bank, 2007).

"Education aims to give you a boost up to the ladder of knowledge. Too often, it just gives you a cramp on one of its rungs.” (Martin H. Fischer)

Despite the fact that education is the essential prerequisite for the process of development but education sector of Pakistan is suffering from many blockades (Glewe and Kremer, 2005). There are five core issues that impede the process of development in education sector such as 1) Quality 2) Access 3) Post Primary education 4) Transition from school to work and 5) Health issues (Tembon and Fort, 2008). Despite this there are three major factors that constraints the education growth in Pakistan such as underprivileged state of government, pitiable state of institutions and lack of competitive environment that restricts the innovation process (Qayyum, et al. 2008). On the other hand other obstructions are government failure, institutional shortcomings, corruption and juridical independence that hamper the process of development in education sector of Pakistan (Kanu, 1996). In addition to this remoteness, extreme poverty, disability, political instability, cost of schooling and policy weakness are the major constraints in education sector of Pakistan (Papagiannis, et al. 1982). Cultural tents always preferred boys to acquire education because it is expected that they will peruse social mobility in order to fulfill the expectations of family (Glaney, 2004). Inflation, unemployment, corruption, rapid population growth and social taboos are the foremost determinants of low literacy rate in Pakistan (Boyle, et al. 2002). Additionally exploitation, political interference and institutional weakness dispossess the children from getting quality education (Hopper, 1991).

\section{Purpose of the study:}

Numerous research works have been done on addressing various aspects of education. But this research is exclusive by addressing education as a prerequisite for the process of development and also diverse blockades that are obstructing this process. The researcher made this research unique by addressing various aspects of this issue. Although ample literature is present on various aspects of education but the researcher made an intellectual address to this issue. An extensive research work has been done by the researcher to demonstrate education as a prerequisite for the process of development in context of Southern Punjab (Pakistan). Numerous studies reveled the strong relationship between education and sustainable development. But studies narrated to developing countries like Pakistan do not endow with ample literature to properly analyze the relationship between education and sustainable development. There are various factors that are accountable for disappointing performance of Pakistan such as corruption, excessive defense spending and sectarian violence. Despite this the government of Pakistan is also striving to follow and achieve the Millennium Development target by 2015. The target of this advocacy plan was to disseminate, generate ownership, build alliances and enhancement of implementation strategies. These endeavors are worth mentioned to comprehend the importance of education as a prerequisite for the process of development. Thus the researcher addressed the following research objectives for the present study:

1. Why education is a prerequisite for the process of development in Southern Punjab (Pakistan)? 
2. What are the objectives of education in the contemporary world?

3. What are the major social goals of education in the contemporary world?

4. What are the major causes of low literacy rate in Southern Punjab (Pakistan)?

5. How education is an effectual tool in combating various social evils that lowers the literacy rate in Southern Punjab (Pakistan)?

6. What are the policy implications for this issue?

\section{Methods and procedure:}

Education is the innermost key to the process of development and it is the influential instrument for reducing poverty and inequality. Education fabricates skilled labor force and contributes to sustainable development. Acquisition and application of knowledge by diverse countries has been governed whether their population has acquired traits and motivations bracket together with prerequisites of educational attainment. Education is always related with occupational attainment because increase in education increases the skill development of the people so that they can contribute their efforts to the self actualization level. There are three major traits that restraint the growth in education sector of Pakistan and they incorporate dilapidated state of government, underprivileged state of institutions and lack of competitive environment. Pertaining to the above mentioned discussion the researcher selected three stakeholders (parents, students and teachers) from the affiliated schools of Board of Intermediate and Secondary Education (BISE) as universe. The researcher selected the students of $10^{\text {th }}$ grade from selected schools as the target population. The teacher in charge and single parental category (father) of the same student (being interviewed) were also included in target population. The major rationale behind selecting the senior most students of the school was that they are mature enough with respect to their age and vision to comprehend the importance of education as a prerequisite for the process of development.

\section{Procedure for sample derivation:}

The researcher selected the sample through multistage sampling technique. In the first stage the researcher selected Multan division out of three divisions (Multan division, Khanewal division and DG Khan division) through simple random selection. Then the researcher selected Multan district out of four districts (Khanewal district, Multan district, Vehari district and Lodhran district) through purposive sampling technique in the second stage of sample selection. The major rationale behind selection of Multan district was that it has the highest ranking for literacy rate among the other districts of Multan division (Multan=59.6\%, Khanewal $=59.2 \%$, Vehari $=55.6 \%$ and Lodhran=52.6\%). Therefore it is obvious that the process of development is highest in Multan district than other districts of Multan division (Khan, 2009). Then the researcher selected $n 1=40$ schools (from BISE, Multan) out of N1=306 schools through systematic random selection in which every $9^{\text {th }}$ school was selected from the purpose of data collection from three stakeholders. Then the researcher interviewed the respondents (Students=200, Parents=200, and teachers=200) through convenient sampling technique. The number of students ranges from 4-7 per school according to difference in population size. The researcher applied law of large number to collect an adequate sample size (N2=600 respondents). 


\section{Data collection and data analysis mechanism:}

The researcher construct interview schedule as a tool for data collection process. The interview schedule was divided into three portions to independently analyze the above mentioned objectives of the research. Both structured and unstructured questions were added to maximize the response rate of the stakeholders and for the purpose of avoiding the response effects. These errors occur due the biased responses of the respondents. Therefore the researcher develops a proper tool to evaluate various aspects of the research being conducted. The researcher used SPSS (version 17) to investigate the results of the coded data. Afterward the researcher applied ANOVA test to compare the responses of the three stakeholders (parents, teachers and students). The researcher coalesced the detailed information into number of categories that permitted the simple description of the data. One-way analysis of variance considers one treatment factor with two or more treatment levels. The goal of the analysis is to test for differences among the means of the levels and to quantify these differences (Rosenbaum, 2002). The formula for one way ANOVA is as follows:

$$
\begin{aligned}
& S S_{\text {total }}=\left(\sum x_{1}{ }^{2}+\sum x_{2}{ }^{2}+\ldots \sum x_{r}{ }^{2}\right)-\frac{\left(\sum x_{1}+\sum x_{2}+\sum x_{r}\right)}{N} \\
& S S_{\text {total }}=\left[\frac{\left(\sum x_{1}\right)^{2}}{n_{1}}+\frac{\left(\sum x_{2}\right)^{2}}{n_{2}}+\ldots \frac{\left(\sum x_{r}\right)^{2}}{n_{r}}\right]-\frac{\left(\sum x_{1}+\sum x_{2}+\ldots . \sum x_{r}\right)}{N} d f_{\text {among }}=\mathrm{r}-1 \\
& S S_{\text {within }}=S S_{\text {total }}-S S_{\text {among }} \\
& M S_{\text {among }}=\frac{S S_{\text {among }}}{d f_{\text {among }}} \\
& F=\frac{M S}{\text { among }}_{\text {Mith }}=\frac{S S_{\text {with }}}{d f_{\text {within }}} \\
& \mathrm{x}=\text { individual observation } \\
& r=\text { number of groups } \\
& \mathrm{N}=\text { total number of observations (all groups) } \\
& \mathrm{n}=\text { number of observations in group }
\end{aligned}
$$

\begin{tabular}{|c|c|c|c|}
\hline \multicolumn{4}{|c|}{ Education as the vital investment in the process of development } \\
\hline \multirow[t]{2}{*}{ Category } & \multicolumn{3}{|c|}{$\begin{array}{l}\text { Percentage of respondents who agreed on these } \\
\text { variables }\end{array}$} \\
\hline & Teachers & Parents & Students \\
\hline Economic development & $70.5 \%$ & $23.5 \%$ & $48.0 \%$ \\
\hline Social development & $48.0 \%$ & $16.0 \%$ & $38.5 \%$ \\
\hline Political development & $12.5 \%$ & $23.0 \%$ & $41.0 \%$ \\
\hline
\end{tabular}

\section{Data analysis:}

Objectives no.1 Education as a prerequisite for the process of development

Table No. 1 


\begin{tabular}{|c|c|c|c|}
\hline Individual development & $66.0 \%$ & $29.5 \%$ & $51.5 \%$ \\
\hline \multicolumn{4}{|c|}{$\begin{array}{l}\text { Education decreases the dependent population and increases the working age } \\
\text { population }\end{array}$} \\
\hline \multirow[t]{2}{*}{ Category } & $\begin{array}{l}\text { Percentage } \\
\text { variables }\end{array}$ & esponden & agreed on these \\
\hline & Teachers & Parents & Students \\
\hline To greater extent & $44 \%$ & $54 \%$ & $65.5 \%$ \\
\hline To some extent & $33 \%$ & $25 \%$ & $20 \%$ \\
\hline \multicolumn{4}{|c|}{ Prerequisites of education in the contemporary world } \\
\hline \multirow[t]{2}{*}{ Category } & $\begin{array}{l}\text { Percentage } \\
\text { variables }\end{array}$ & esponden & agreed on these \\
\hline & Teachers & Parents & Students \\
\hline Innovation & $68 \%$ & $20.5 \%$ & $46 \%$ \\
\hline Broad vision & $63.5 \%$ & $47.5 \%$ & $44 \%$ \\
\hline Market awareness & $58.5 \%$ & $72 \%$ & $40 \%$ \\
\hline \multicolumn{4}{|c|}{ Non-economic benefits of education } \\
\hline \multirow[t]{2}{*}{ Category } & $\begin{array}{l}\text { Percentage } \\
\text { variables }\end{array}$ & esponden & agreed on these \\
\hline & Teachers & Parents & Students \\
\hline Low fertility & $78 \%$ & $41 \%$ & $57 \%$ \\
\hline Participation in democracy & $60.5 \%$ & $34 \%$ & $47.5 \%$ \\
\hline Reduced crime & $32 \%$ & $25 \%$ & $29 \%$ \\
\hline \multicolumn{4}{|c|}{ Socio-political and economic adjustment of an individual in society } \\
\hline \multirow[t]{2}{*}{ Category } & $\begin{array}{l}\text { Percentage } \\
\text { variables }\end{array}$ & esponden & agreed on these \\
\hline & Teachers & Parents & Students \\
\hline To greater extent & $41 \%$ & $33 \%$ & $48 \%$ \\
\hline To some extent & $63 \%$ & $36 \%$ & $28.5 \%$ \\
\hline
\end{tabular}

\section{Discussion:}

Table No. 1 shows that education is the fundamental investment in the process of sustainable development. The table shows the responses of the three stakeholders (teachers, parents and students). Thus $70.5 \%$ teachers, $23.5 \%$ parents and $48 \%$ students agree that education is the vital investment in economic development. Hannuman and Buchmann (2005) concluded that education expansion improves the economic welfare, perk up the health status, reduces income inequalities, ensure demographic advantages and promote democratization. Therefore the importance of education cannot be disregarded because it diminishes the dependent population and increases the working age population. While $48 \%$ teachers, $16 \%$ parents and $38.5 \%$ students agree that education is the vital investment in social development. On the other hand $12.5 \%$ teachers, $23 \%$ parents and $41 \%$ students agree that education is the vital investment in political development. On the top of it $66 \%$ teachers, $29.5 \%$ parents and $51.5 \%$ students agree that education is the vital investment in individual development. Education is the most important asset to enhance the human abilities and capabilities that will 
play a significant role in socio-political and economic development of the country. At the micro level education is correlated with high income generating opportunities. At the macro level education produces skilled labor force and contributed to sustainable development of any country (Akram and Khan, 2007). In addition to this education decreases the dependent population and increases the working age population. The table illustrates that $44 \%$ teachers, $54 \%$ parents and $65.5 \%$ students agree to greater extent that education amplifies the working age population and lessens the dependent population. While 33\% teachers, 25\% parents and $20 \%$ students agree to some extent that education increases the working age population and decreases the dependent population. The working age population was $48.8 \%$ in 1981, $46.7 \%$ in 1998, 57.3\% in 2004 and will be 61.7\% in 2015. This all becomes possible due to increase in working population and decrease in dependent population. On the other hand age structure has been changing in the developing countries due to demographic transition that contributes to economic development of the country because it increases the proportion of working age population and decreases the dependent population (National Education Policy, 2009). Over and above the above mentioned table also depicts the responses of the teachers, parents and students about the foremost prerequisites of education in the contemporary world. Here the table reveals that $68 \%$ teachers, $20.5 \%$ parents and $46 \%$ students agree that innovation is the most important prerequisite of education in the contemporary world. Khan (2002) concluded that education equip the people with the innovative ideas. Education helps the people to utilize their potentials to the self-actualization level. Education also enhances the cognitive powers of the people and make them innovative. On the other hand $63.5 \%$ teachers, $47.5 \%$ parents and $44 \%$ students agree that broad vision is the most important prerequisite of education in the contemporary world. Whereas $58.5 \%$ teachers, $72 \%$ parents and $40 \%$ students agree that market awareness is the noteworthy prerequisite of education in the contemporary world. Orazem and King (2007) concluded that education enhances labor market productivity and income growth for all, yet educating women have beneficial effects on social well-being not always measured by market. The table also illustrates the non-economic benefits provided by education. Thus $78 \%$ teachers, $41 \%$ parents and $57 \%$ students agree that low fertility rate is the major non-economic benefit provided by education. The illiterate women have usually higher fertility rate than those women who accomplish higher education levels. Similarly women who are employed but have no education have advanced fertility rates (like employees) than those women who are employed and educated (Hakim, 1994). On the other hand 60.5\% teachers, $34 \%$ parents and $47.5 \%$ students agree that better participation in democracy is the major non-economic benefit provided by education. Over and above $32 \%$ teachers, $25 \%$ parents and $29 \%$ students agree that diminished crime rate is the major non-economic benefit endow with education. As mentioned by Cassen (1994) education accomplishment alters parental perceptions about the advantages of small families, brings changes in women status and change in socio-economic aspirations. Thus educated women have low fertility rate than uneducated women. On the other hand Fasih (2008) mentioned that primary education not only prepare the individuals for better earnings but also for numerous non-economic benefits like 1) Low infant mortality 2) Better participation in democracy 3) Reduced crime rate and 4) Sustainable development. Despite these facts education is an obligatory prerequisite in the contemporary world for the purpose of socio-political and economic adjustment of an 


\section{Mll Macrothink}

International Journal of Learning \& Development

ISSN 2164-4063

2012, Vol. 2, No. 2

individual in the society (World Bank, 2007). Therefore the above mentioned table depicts that $41 \%$ teachers, $33 \%$ parents and $48 \%$ students agree to the greater extent that education provides socio-political and economic adjustment of an individual in the society whereas $63 \%$ teachers, $36 \%$ parents and $28.5 \%$ students agree to only some extent. Despite of larger differences in social structures and historical backgrounds education sector have to face serious confronts. But despite this fact education helps the individuals to make their adjustments in the society.

\section{Objective no. 2 Objectives and social goals of education in the contemporary world}

Table No. 2

\begin{tabular}{|l|l|l|l|}
\hline \multirow{2}{*}{ Objectives of education regarding individual development } \\
\hline & $\begin{array}{l}\text { Percentage of } \\
\text { Variables }\end{array}$ & \multicolumn{2}{l|}{} \\
\cline { 2 - 4 } & Teachers & Parents & Students \\
\hline Original thinking & $55 \%$ & $35.5 \%$ & $29.5 \%$ \\
\hline Analytical thinking & $66 \%$ & $41.5 \%$ & $35 \%$ \\
\hline Responsible member of community & $17.5 \%$ & $51 \%$ & $62.5 \%$ \\
\hline Global citizen & $14.5 \%$ & $38.5 \%$ & $68 \%$ \\
\hline Most important social goals of education & Percentage of & respondents who agree on these \\
\hline \multirow{4}{*}{ Category } & variables & \multicolumn{2}{l|}{} \\
\hline & Teachers & Parents & Students \\
\hline Tolerant society & $46.5 \%$ & $23 \%$ & $65 \%$ \\
\hline Skilled labor force & $56 \%$ & $42 \%$ & $24.5 \%$ \\
\hline Economic growth & $47.5 \%$ & $19.5 \%$ & $66.5 \%$ \\
\hline Innovation process & $70.5 \%$ & $46.5 \%$ & $38 \%$ \\
\hline Social cohesion & $57.5 \%$ & $37 \%$ & $49.5 \%$ \\
\hline Sustainable development & $74 \%$ & $40.5 \%$ & $57 \%$ \\
\hline Civic responsibility & $56.5 \%$ & $38.5 \%$ & $21 \%$ \\
\hline Crafting new knowledge & $68.5 \%$ & $44 \%$ & $15.5 \%$ \\
\hline
\end{tabular}

\section{Discussion:}

Table no. 2 illustrates the objectives and social goals of education in the contemporary world regarding individual development. Thus 55\% teachers, 35.5\% parents and $29.5 \%$ students agree that original thinking is the objective of education regarding the individual development. On the other hand $66 \%$ teachers, $41.5 \%$ parents and $35 \%$ students agree that analytical thinking is the objective of education regarding the individual development. Education is an important tool that empowers the individuals and makes them responsible for their own deeds. Education is also an effective instrument for making the original and analytical ideologies of the people and empowers them to contribute their efforts for the development of the country (Siddique, 2007). On the other hand $17.5 \%$ teachers, $51 \%$ parents and $62.5 \%$ students agree that making the people as responsible members of the community is the intention of education regarding the individual development. On the top of it $14.5 \%$ teachers, $38.5 \%$ parents and $68 \%$ students agree that making the people as global citizens is the 
purpose of education in the contemporary world. The table also portrays the most imperative social purposes of education. Consequently the researcher also describes the responses of the teachers in this above cited table. Thus $46.5 \%$ teachers, $23 \%$ parents and $65 \%$ students agree that formation of tolerant society is the crucial social ambition of education in Southern Punjab (Pakistan). On the other hand 56\% teachers, $42 \%$ parents and 24.5\% students agree that formation of skilled labor force is the imperative social aspiration of education. Over and above 47.5\% teachers, $19.5 \%$ parents and $66.5 \%$ students agree that economic growth is the most important social goal of education. Education is becoming an optimal demand for income determination and economic growth but the access to education and years of completion of education depends strongly on family income because outsized family income will ensure more chances for school enrollments than lower family incomes. Likewise public investment on education is also the strapping determinant. Financial constraints are noteworthy to limit the access to secondary education especially for the girls. Similarly female participation in education sector is more conditioned by family wealth as compared to boys (Cheechi, 2003). Whereas $70.5 \%$ teachers, $46.5 \%$ parents and $38 \%$ students agree that innovation process is the essential social objective of education in the present era. On the other hand $57.5 \%$ teachers, $37 \%$ parents and $49.5 \%$ students agree that social cohesion is the most important social ambition of education. Whereas $74 \%$ teachers, $40.5 \%$ parents and $57 \%$ students agree that sustainable development is the indispensable social rationale of education in the contemporary world. While $56.5 \%$ teachers, $38.5 \%$ parents and $21 \%$ students agree that civic responsibility is the indispensible social ambition of education. Besides this $68.5 \%$ teachers, $44 \%$ parents and $15.5 \%$ students agree that crafting of new knowledge is the most important social goal of education. Despite this fact education institutions do not supply adequate skilled labor force that is the major hurdle in the process of development in Pakistan. There are three major factors that constraints the education growth in Pakistan (such as poor state of government, poor state of institutions and lack of competitive environment that restricts the innovation process)(Heyneman and Loxley, 1983). Thus there are numerous impediments such as government failure, institutional shortcomings, corruption and juridical independence that hamper the process of development in education sector of Pakistan. Despite this fact education institutions do not supply passable skilled labor force that is the major blockage in the process of development in Pakistan (Qayyum, et al. 2008).

\section{Objective no. 3 Causes of low literacy rate in Pakistan}

Table No. 3

\begin{tabular}{|l|l|l|l|}
\hline Causes of low literacy rate in Pakistan & \multicolumn{3}{l|}{} \\
\hline \multirow{2}{*}{ Variables } & \multicolumn{3}{l|}{$\begin{array}{l}\text { Percentage } \\
\text { agree on these variables }\end{array}$} \\
\cline { 2 - 4 } & Teachers & Parents & Students \\
\hline Social taboos & $55.5 \%$ & $40 \%$ & $18 \%$ \\
\hline Low socio-economic status of the parents & $72.5 \%$ & $22.5 \%$ & $54 \%$ \\
\hline Child labor (Intrahousehold and Extrahousehold) & $61.5 \%$ & $19.5 \%$ & $43.5 \%$ \\
\hline Illiteracy of parents & $73.5 \%$ & $12 \%$ & $58 \%$ \\
\hline Institutional weakness & $25.5 \%$ & $60.5 \%$ & $19 \%$ \\
\hline Lack of uniformity in educational structures & $16 \%$ & $41 \%$ & $47 \%$ \\
\hline
\end{tabular}




\begin{tabular}{|l|l|l|l|}
\hline Policies not suited to local conditions & $25.5 \%$ & $49 \%$ & $10.5 \%$ \\
\hline Corruption & $8 \%$ & $61.5 \%$ & $48.5 \%$ \\
\hline Limited family earnings & $62.5 \%$ & $20 \%$ & $41 \%$ \\
\hline Unemployment & $50.5 \%$ & $27 \%$ & $33 \%$ \\
\hline Inflation & $49.5 \%$ & $73.5 \%$ & $39 \%$ \\
\hline Exploitation & $33.5 \%$ & $51.5 \%$ & $26.5 \%$ \\
\hline Rapid population growth & $69 \%$ & $37.5 \%$ & $11.5 \%$ \\
\hline Political instability & $67 \%$ & $9 \%$ & $24.5 \%$ \\
\hline Poverty & $70.5 \%$ & $34.5 \%$ & $56 \%$ \\
\hline Inequality & $20.5 \%$ & $45 \%$ & $56.5 \%$ \\
\hline Political instability & $54 \%$ & $24 \%$ & $13.5 \%$ \\
\hline Injustice & $27.5 \%$ & $34.5 \%$ & $68.5 \%$ \\
\hline Low literacy rate & $67.5 \%$ & $45 \%$ & $38 \%$ \\
\hline Lack of confidence in public schools & $75 \%$ & $23 \%$ & $46 \%$ \\
\hline Political interference & $68.5 \%$ & $34.5 \%$ & $22 \%$ \\
\hline Teachers absenteeism & $18 \%$ & $39.5 \%$ & $66 \%$ \\
\hline Ghost schools & $39.5 \%$ & $42.5 \%$ & $63.5 \%$ \\
\hline Cheating in examinations & $59 \%$ & $41 \%$ & $9.5 \%$ \\
\hline Inadequate decision making of the parents & $73.5 \%$ & $18 \%$ & $52.5 \%$ \\
\hline
\end{tabular}

\section{Discussion:}

Table no. 3 depicts the causes of low literacy rate in Pakistan. Thus 55.5\% teachers, $40 \%$ parents and $18 \%$ students agree that social taboos is the major cause of low literacy rate in Pakistan. On the other hand $70.5 \%$ teachers, 34.5\% parents and 56\% students agree that poverty is the major cause of low literacy rate in Pakistan. There is a strong relationship between poverty and educational deprivation. Poverty operates at the country level depriving the people from education. At the household level the parents are dispossessed of giving schooling to their children (Watkins, 2000). On the other hand $61.5 \%$ teachers, $19.5 \%$ parents and $43.5 \%$ students agree that child labor (Intrahousehold and Extrahousehold) is the foremost cause of low literacy rate in Pakistan. Thus $73.5 \%$ teachers, $12 \%$ parents and $58 \%$ students agree that parental illiteracy is the foremost cause of low literacy rate in Pakistan. Over and above $25.5 \%$ teachers, $60.5 \%$ parents and $19 \%$ students agree that institutional weakness is the major cause of low literacy rate in Pakistan. While 16\% teachers, $41 \%$ parents and $47 \%$ students agree that lack of uniformity in existing educational structures is the foremost cause of squat literacy rate in Pakistan. The determinants of education completion at the primary, middle and high school level are individual and household factors such as household income, parental education and rich array of community characteristics. These community characteristics comprise of rural urban location, level of urban development, distance from school and financial status of the parents (Tanseel, 2002). And 25.5\% teachers, $49 \%$ parents and $10.5 \%$ students agree that policies not suited to local conditions and requirements is the major cause of low literacy rate in Pakistan. National Education Policy (2009) analyzed that the barricades to low literacy rate are social taboos, poverty, child labor, illiteracy of parents, 
institutional weakness and outfitted policies of education to the local conditions. At the provisional level there is lack of uniformity in the existing structures. Turrent and Oketch (2009) concluded that derisory legal framework in such areas as compulsory education, child labor, lack of enforcement of existing laws and policies, (related to many things e.g. corporal punishment, parental illiteracy, child labor, insufficient national budgetary allocations of resources, segregation of education from existing national frameworks, lack of political will, political turnover of the government, low socio-economic status of the parents and negative political intervention in education sector). The table also illustrates the foremost social evils that obstruct the process of development through low literacy rate. The table demonstrates the responses of the teachers, parents and students. Thus table demonstrates that $8 \%$ teachers, $61.5 \%$ parents and $48.5 \%$ students agree that corruption is the major social malevolence that impedes the process of development through low literacy rate. Therefore $62.5 \%$ teachers, $20 \%$ parents and $41 \%$ students agree that limited family earning is the social evil that hampers the process of development through low literacy rate. Summers (1994) argue that limited family earning is the major determinant of low literacy rate in Pakistan. The researcher argues that limited family earnings raise the issue of direct and indirect cost of schooling and thus contributes to low quality education and biased attitude of the parents about their children enrollment. On the other hand 50.5\% teachers, 27\% parents and 33\% students agree that unemployment is the major social evil that hampers the process of development through low literacy rate. Thus there are many blockades such as government failure, institutional shortcomings, corruption, limited family earning, inflation and juridical independence that impede the process of development in education sector of Pakistan. Despite this fact education institutions do not supply skilled labor force that is the major stumbling block in the process of development in Pakistan (Qayyum etal, 2008). While 49.5\% teachers, $73.5 \%$ parents and 39\% students agree that inflation is the major social evil that hampers the process of development through low literacy rate. While $64 \%$ teachers, $37.5 \%$ parents and $11.5 \%$ students agree that rapid population growth is the foremost social evil that hampers the process of development through low literacy rate. Kazmi (2005) concluded that there are many social evils in the developing countries like corruption, unemployment, low earnings, inflation, exploitation, hasty population growth, political instability and the major cause behind these issues is low literacy rate in Pakistan. Bushmann and Hannum(2001) analyzed that education inequality is the foremost blockade that reduces the literacy rate and education quality. The progress of educational inequality in various areas is obvious like: Macro-structural forces shaping education and stratification, relationship between family backgrounds and educational outcomes, school impacts and educational impact on socio-economic mobility. The researcher illustrates the responses of the teachers, parents and students. Qureshi (2004) concluded that low socio-economic status of the parents is the major factor responsible for low literacy rate of Pakistan. Cassen (1994) analyzed that especially the women become the victim of extreme inequality due to poverty of parents. On the other hand $20.5 \%$ teachers, $45 \%$ parents and $56.5 \%$ students agree that inequality is the major reason of social exclusion of people from education sector. On the top of it $67 \%$ teachers, $9 \%$ parents and $24.5 \%$ students agree that political instability is the major cause of social exclusion of people from education sector. The researcher concluded the work of Papagiannis, et al. (1982) that there are various 
socio-political and economic blockades of development in education sector like remoteness, extreme poverty, disability, nomadic living, conflict, political instability, abuse or neglect at home and non-availability of access to education sector. These obstructions hamper the process of development in education sector. Whereas $27.5 \%$ teachers, $34.5 \%$ parents and $68.5 \%$ students agree that injustice is the major cause of social exclusion of people from education sector. Thus $67.5 \%$ teachers, $45 \%$ parents and $38 \%$ students agree that low literacy rate is the foremost cause of social exclusion of people from education sector. In Pakistan there are three other core issues that are related with low literacy rate in Pakistan. They are low education spending, squat female literacy rate and weak policy making to close the gender gap. Education disparity is the chief hurdle for low female participation in workforce for the development of any country. As PRSP (2003) concluded that teachers shortage, teachers absenteeism, inadequate attention of teachers to every student and lack of teachers availability are the dominant causes of low access of parents and their children to education sector. Low access of children to schools has numerous reasons and the foremost reasons are political interference, lack of commitment of parents towards their children education, teachers absenteeism, ghost schools, cheating in examinations, low confidence on public schools and parental preference to private schools. The researcher portrays the responses of the teachers, parents and students. The responses of the teachers are cited in the form of percentages in the above mentioned table. Thus $75 \%$ teachers, $23 \%$ parents and $46 \%$ students agree that lack of confidence in public sector schools is the dominant cause of low access of children and their families to education sector. On the other hand $68.5 \%$ teachers, $34.5 \%$ parents and $22 \%$ students agree that political interference is the dominant cause of low access of children and their families to education sector. As mentioned by Papagiannis, et al. (1982) there are various socio-political and economic barriers of development in education sector of Pakistan like political interference by the government that have negative impact on quality of education, direct cost of schooling, indirect cost of schooling, political instability, abuse or neglect at home and non-availability of access to education sector. Other challenges include the underinvestment in education sector, lack of accountability, lack of potential for resource mobilization, high dropout rates, teachers absenteeism as well as low availability and accessibility to education sector (PRSP, 2003). In addition to these $39.5 \%$ teachers, $42.5 \%$ parents and $63.5 \%$ students agree that presence of ghost schools is the dominant cause of low access of children and their families to education sector. Over and above 59\% teachers, $41 \%$ parents and $9.5 \%$ students agree that cheating in examinations is the prevailing cause of low access of children and their families to education sector. Consequently $73.5 \%$ teachers, $18 \%$ parents and $52.5 \%$ students agree that inadequate decision making of the parents is the dominant cause of low access of children and their families to education sector. As mentioned by Alderman (1998) there are three major factors that becomes the major cause of high dropout rates of the students. These factors include child labor, school fees and school availability. Mahmood, et al. (1994) concluded that decision making plays a crucial role in this regard because child labor, deprivation from schooling and augmented fertility rate depends upon decision making of the household to educate their children. Dropout rates of the children may be one of the determinants of child labor. Other determinant is poor household with low adult employment. On the other hand Hazarika and Bedi (2003) concluded that Intrahousehold 


\section{Macrothink Institute ${ }^{\mathrm{TM}}$}

and Extrahousehold child labor have negative impacts on schooling access of children residing in rural areas of Pakistan.

One Way ANOVA test application on stated hypotheses:

H1: Education is the prerequisite for the process of development.

\begin{tabular}{|l|l|l|l|l|l|}
\hline Source & DF & SS & MS & & \\
\cline { 1 - 4 } Factor & 2 & 151.23 & 75.61 & F & P \\
\cline { 1 - 3 } Error & 597 & 1300.31 & 2.18 & 3.72 & 0.000 \\
\cline { 1 - 3 } Total & 599 & 1451.54 & & & \\
\cline { 1 - 4 }
\end{tabular}

H2: Education decreases the dependent population and increases the working age population.

\begin{tabular}{|c|c|c|c|c|c|}
\hline Source & DF & SS & MS & \multirow{4}{*}{$\begin{array}{l}\mathbf{F} \\
1.86\end{array}$} & \multirow{4}{*}{$\begin{array}{l}\mathbf{P} \\
0.005\end{array}$} \\
\hline Factor & 2 & 9.82 & 4.91 & & \\
\hline Error & 597 & 1572.77 & 2.63 & & \\
\hline Total & 599 & 1582.60 & & & \\
\hline
\end{tabular}

H3: Education is the optimal demand for income determination.

\begin{tabular}{|c|c|c|c|c|c|}
\hline Source & DF & SS & MS & \multirow{4}{*}{$\begin{array}{l}\mathbf{F} \\
39.54\end{array}$} & \multirow{4}{*}{$\begin{array}{l}\mathbf{P} \\
0.000\end{array}$} \\
\hline Factor & 2 & 136.81 & 68.41 & & \\
\hline Error & 597 & 1032.86 & 1.73 & & \\
\hline Total & 599 & 1169.67 & & & \\
\hline
\end{tabular}

H4: Lack of confidence on public sector schools is the major determinant of low enrollment rate of students.

\begin{tabular}{|l|l|l|l|l|l|} 
Source & DF & SS & MS & & \\
\cline { 1 - 4 } Factor & 2 & 47.85 & 68.41 & F & P \\
\cline { 1 - 3 } Error & 597 & 897.74 & 1.73 & 0.000 \\
\cline { 1 - 3 } Total & 599 & 1169.67 & & \\
\cline { 1 - 3 }
\end{tabular}

H5: Education increases the socio-political and economic adjustment of an individual in the society.

\begin{tabular}{|c|c|c|c|c|c|}
\hline \begin{tabular}{|l|} 
Source \\
\end{tabular} & DF & SS & MS & \multirow{4}{*}{$\begin{array}{l}\mathbf{F} \\
13.84\end{array}$} & \multirow{4}{*}{$\begin{array}{l}\mathbf{P} \\
0.001\end{array}$} \\
\hline Factor & 2 & 140.90 & 70.45 & & \\
\hline Error & 597 & 3033.19 & 5.09 & & \\
\hline Total & 599 & 3174.10 & & & \\
\hline
\end{tabular}

H6: Low quality education is the major determinant of low enrollment rate of students.

\begin{tabular}{|l|l|l|l|l|l|}
\hline Source & DF & SS & MS & & \\
\cline { 1 - 4 } Factor & 2 & 17.91 & 8.96 & F & P \\
\cline { 1 - 3 } Error & 597 & 901.35 & 1.51 & 5.93 & 0.003 \\
\cline { 1 - 3 } Total & 599 & 919.35 & & & \\
\hline
\end{tabular}

H7: Education empowers the marginalized components (women, disabled and minorities) of the society.

\begin{tabular}{|l|l|l|l|l|l|}
\cline { 1 - 4 } Source & DF & SS & MS & & \\
\cline { 1 - 4 } Factor & 2 & 81.94 & 40.97 & F & P \\
Error & 597 & 876.01 & 1.47 & 27.92 & 0.002 \\
\hline Total & 599 & 957.96 & & & \\
\hline
\end{tabular}




\section{Discussion:}

Development is the process of growth towards self reliance and gratification. It is the process by which the individuals, groups and communities acquire the means to be responsible for their own livelihoods, welfare and future. The opposite of development is the process of dedevelopment when the potential of self reliance and development deteriorates and it results in war, civil unrest and natural calamity (Kinsbury, et al. 2004). Education is the prerequisite for the process of development $(\boldsymbol{p}=\mathbf{0 . 0 0 0})$. Without education development can never be attained. Thus development is a multidimensional phenomenon. Education contributes to the process of development by making noteworthy alterations in social structures, popular attitudes, accelerated economic growth (in terms of income determination with $\boldsymbol{p}=\mathbf{0 . 0 0 0}$ ) and diminished inequality (Sataton, 2007). Education in the contemporary world is no more the question of East or West, Socialist or Capitalist and rich or poor country. These distinguishing influences have been diminished over time. Now education has fundamental importance all over the globe. The new demand for augmented professionalism emerges on the part of education system. Thus education enhances the abilities of the people and makes them independent ( $\boldsymbol{p = 0 . 0 0 0 )}$ (Hanusheck, 1995). During the past fifteen years more attention has been drawn towards the right of education because the most imperative blockade of education is parental obligation whereas one considers it is the state charge only. Thus education policies are swiftly detrimental because more diversity in education sector leads towards more responsibilities for the parents and more autonomy for their children. The right to education and freedom dimension empowers the marginalized components of the society to take part in the process of development $(\boldsymbol{p = 0 . 0 0 0})$. Over the lifetime of an individual the investment in cognitive and non cognitive skills fabricates high returns to education sector and this will lower the cost of afterward investment making learning at the later stage more proficient (Cunha, et al. 2006).

\section{According to Article 37 (Constitution of Pakistan)}

"The State shall remove illiteracy and provide free and compulsory secondary education within the minimum possible period; make technical and professional education generally available and higher education equally accessible to all on the basis of merit".

\section{Recently, through a Constitutional Amendment No 18.}

"Free and compulsory education for the children aged 5 to 16 years has been declared a fundamental right of education."

\section{Article 25-A of the Constitutions provides that:}

"The state shall provide free and compulsory education to all children of the age of five to sixteen years in such manner as may be determined by the law."

But regrettably in Pakistan (Punjab) literacy ratio is 59.3\% in rural areas and $74.6 \%$ in urban areas. Attendance ratio shows that $53 \%$ eligible population is attending primary school and $29 \%$ of eligible population is attending secondary school. There is dilemma of enrollment 
in primary education level. In 2008 literacy rate of Southern Districts of Punjab does not fall below 50\% (Khan, 2009). In addition to this the major obstruction in education sector arises when parents are not able to submit fees then they have to enroll their children in public schools with poor infrastructure and low quality education (Deininger, 2003). The other determinant is lack of confidence on public schools $(\boldsymbol{p}=\mathbf{0 . 0 0 0})$ due to various factors. Poor households prefer public schools for the better educational future of their children according to their financial resources (Handa, 1999). If private school fees as well as distance are lowest and the quality of private school environment is sky-scraping then the parents send their children to private schools. Mostly private school enrollment is sky-scraping as compared to public schools because private school performance is better than public schools whether it is the matter of infrastructure or teaching methodologies (Eaterline, 1981). Despite these factors low adult literacy rate, stumpy enrollment rate, high dropout rate, high cost of schooling, parental disinterest in educating their children, lack of proper school infrastructure, absenteeism of teachers and low quality education are the major barricades that have negative impact on literacy rate of Pakistan (Alderman, 2001). Thus low quality education is the major determinant of low enrollment rate of students $(\boldsymbol{p}=\mathbf{0 . 0 0 3})$. Thus in underdeveloped countries the foremost concern is low quality education that becomes the foremost motivator for the students to learn less despite off spending greater time in school. The major issue in this regard is the teachers style of teaching and school environment (Heyneman and Loxley, 1983). High quality education is the necessary prerequisite for the success of an individual in attaining high opportunities that in turn produces quality standard labor market outcomes (Hanushek and Woessmann, 2007).

\section{Conclusion:}

After revering all the analysis the researcher concluded that education is an asset for the people of Pakistan. It is the driving force for the development of every country. Education extension perks up the economic welfare and diminishes income inequalities. It also ensures demographic benefits, economic security and democratization. Education is an effectual tool in combating poverty through skilled labor force and plays a momentous role in the phenomenal advancement of Pakistan. Moreover education is a fundamental asset to empower people who are forbidden to participate in the decision making process. Education meets the needs of the learners in terms of human rights and gender equality. The outcomes of education facilitates the individual to survive in the labor market and these outcomes are cognitive skills, technical skills, general and specific knowledge and values that helps to prepare the individuals for their professional lives. History has witness that no nation has been able to accelerate in development process without taking into consideration this aim as prerequisite. Pakistan is one of the developing countries that are striving for improvement in this area. But regrettably many obstructions in education sector diminish its effectiveness. These blockades are inadequate resources, cultural tenets, lack of well designed curriculum, low parental education and obstinate socio-cultural practices. In addition to this there are countless factors that divest the children from school like direct cost of schooling, indirect cost of schooling and lack of implementation strategies to combat various social evils. 


\section{Policy implications:}

1. Government should increase budget allocation for education sector of Pakistan.

2. Government should augment welfare services so that the poor families should focus on educational attainment of their children.

3. Government should instigate positive competition between the state schools and private schools so that both can contribute to amplify the literacy rate of Pakistan.

4. Government should introduce such curriculum that must be pertinent to the present day needs.

5. Government should introduce such programmes that introduce creative ideas, motivation, energy, idealism, national integration and self-discipline among the students.

6. Government should focus its attention on gender inequality by means of advocacy and better research.

7. Government should focus on escalating the number of schools so that parents and students have an easy access to education at least at the primary level.

8. Government should ensure future economic security and incentives to the teachers so that they can work without any uncertainty.

9. Government should ensure participation from the private sector so that the uniformity in education sector can be accomplished.

10. Government should ensure strict monitoring system and management of teaching workforce.

11. Government should design the curriculum in apposite sequence with suitable examples so that students can easily conceptualize this curriculum.

12. Government should abolish the school fees particularly at the primary level.

13. Government should encourage parents and reward their efforts regarding their children academic achievement.

14. Government should encourage research projects and their critical analysis in education sector so that ample data can be collected for the policy makers in education sector of Pakistan.

15. Government should encourage the appointment of female teachers so that the biasness regarding the female teachers appointment can be abridged.

16. Government should encourage the role of NGO's in provision of educational services to maximum population.

17. Policy makers should ensure policy coherence to achieve educational objectives in Pakistan.

18. Quality of education can be increased by making it an outcome based education which should be based on the following premises:

1. All students can learn and succeed in the same way.

2. Successful learning even promotes more conceptual ideas.

3. Education institutions and teachers control many conditions that determine whether or not students are successful at learning.

19. Any education policy that is designed to achieve high literacy rate must focus on the following premises: 
1. A clear purpose of the total programme of the study.

2. Clearly defined outcomes for the total programme.

3. Explicit links between outcomes of each section of the programme and overall outcomes.

4. Clear statement of all the clauses so the clarity should be ensured.

20. Quality of education can be enhanced by using the students ideas in pertinent ways like:

1. Acknowledging: Repeating students' main statements given by students are appreciated.

2. Modifying: Rephrasing students' ideas in teachers' works.

3. Applying: Using the students ideas to take the next step to solve any problem

4. Comparing: Showing similarities and differences in the ideas of many students.

5. Summarizing: Using what was said by the students to revise key points. 


\section{References:}

1. Aikman, S \& Unterhalter, E. 2005. Beyond access: Transforming policy and practice for gender equality in education. London: Oxford.

2. Akram, M. and Khan, F.J. 2007. "Public Provision of Education and Government Spending in Pakistan.” PIDE Working Papers, Islamabad, Pakistan.

3. Alderman, H. and E.M. King. 1998. "Gender Differences in Parental Investment in Education." Structural Change and Economic Dynamics, Vol.9, No.4, pp.453-468.

4. Alderman, H., P.I. Orazem and E.M. Paterno. 2001. "School Quality, School Cost and Public/Private School Choices of Low Income Households in Pakistan.” The Journal of Human Resources, Vol. 36, No. 2, pp.304-326.

5. Anderson, R. \& Dexter, S. 2005. School technology leadership: An empirical investigation of prevalence and effect. Education Administration Quarterly, 1:49-82. Boston: Allyn and Bacon.

6. Boyle, S.A., J. Mace, M. Sibbons. 2002. "The Costs of Sending Children to School: A Six-Country Comparative Study, Synthesis Report, Education Research Papers 12830. Department of International Development (DFID), UK.

7. Bushmann, C. and E. Hannum. 2001. "Education and Stratification in Developing Countries: A Review on Theories and Research." Annual Review of Sociology, Vol.27, pp.77-102.

8. Cassen, R.H. 1994. "Population and Development: A Survey." World Development, Vol.4, No.10, pp.785-830.

9. Checchi, D. 2003. "Inequality in Incomes and Access to Education." A Cross Country Analysis (1960-1995).” Labor, Vol.17, No.2, pp.153-201.

10. Cunha, F., J. J. Heckman, L. Lochner and D.V. Materterov. 2006. "Interpreting the Evidence on Life Cycle Skill Formation." Handbook of Education Economics, ed. Eric Hanusheck and F. Welch, 697-812. Amsterdam: Elsevier North Holland.

11. Deininger, K. 2003. "Does cost of Schooling Affect Enrollment by the Poor Universal Primary Education in Uganda." Economics of Education Review, Vol.22, No.3, pp.291-305.

12. Eaterline, R.A. 1981." Why isn't the Whole World Developed?" Journal of Economic History, Vol.41, No.1, pp.1-19.

13. Fasih, T. 2008. "Linking Education Policy to Labor Market Outcomes." The International Bank for Reconstruction and Development/ The World Bank Washington DC.

14. Glandney, D.C. 2004. "Dislocating China. Muslims, Minorities and other Subaltern Subjects. Hurst and Company, London.

15. Glewe, P. and M. Kremer. 2005. "Schools, Teachers and Education Outcomes in Developing Countries." Second Draft of Handbook on the Economics of Education.

16. Hakim, A. 1994. "Factors Affecting Fertility in Pakistan." The Pakistan Development Review, Vol.33, No.4, pp.685-709.

17. Handa, S. 1999. "Raising Primary School Enrollment in Developed Countries: The Relative Importance of Supply and Demand." International Food Policy Research Institute, Washington, DC. 


\section{Mll Macrothink}

18. Handa, S. 1999. "Raising Primary School Enrollment in Developed Countries: The Relative Importance of Supply and Demand." International Food Policy Research Institute, Washington, DC.

19. Hannum, E. and C. Buchmann.2005. "Global Educational Expansion and Socio-Economic Development: An Assessment of Findings from the Social Sciences." World Development, Vol.33, No.3, pp.333-353.

20. Hanusheck, E.A. and L.Woesmann. 2007. "The Role of Education Quality for Economic Growth.” Policy Research Paper No. 4122, World Bank, Washington, DC.

21. Hanuskeck, E.A. 1995. "Interpreting Recent Research on Schooling in Developing Countries." The World Bank Research Observer, Vol.10, No.2, pp.227-246.

22. Hazarika, G. and A. Bedi. 2003. "Schooling Costs and Child Work in Rural Pakistan." Journal of Development Studies, Vol.39, No.5, pp.29-64.

23. Heyneman, S. P. and W.A. Loxley. 1983. "The Effect of Primary School Quality on Academic Achievement across Twenty Nine High and Low Income Countries." The American Journal of Sociology, Vol.88, No.6, pp.1162-1194.

24. Hooper, B. 1991. "Gender and Education in Epstein ed. Chinese Education: Problems, Policies and Prospects. Garland Publishing Inc., New York \& London.

25. Jongbloed, B. 2004. "Funding Higher Education: Options, Trade offs and Dilemmas." Paper presented at the Fulbright Brainstorms 2004." New Trends in Higher education, Lisbon, Portugal, 24-25 September, 2004.

26. Kanu, Y. 1996. "Educating Teachers for the Improvement of the Quality of Basic Education in Developing Countries." International Journal of Educational development, Vol.16, No.2, pp.173-184.

27. Kazmi, S.W. 2005. "Role of Education in Globalization: A Case of Pakistan." SAARC, Journal of Human Resource Development.

28. Kennedy, C.H. and Baxter, C. 2000. "Pakistan 2000." Lexington Books, Published in the United States of America by Lexington Books.

29. Khan, A. 2009. "Education Order in Punjab. A District level study." Centre for Research in Economics and Business Lahore School of Economics in Pakistan Institute of Development Economics.

30. Khan, H. 2002. "National Diagnostics of Head Teachers in Pakistan, Improving School Management in Asia: Capacity Building for Head Teachers . AEPAM, Islamabad Moe.

31. Khan, M.A. 2003. " Public Expenditures, Poverty and Human Development: Experience of Pakistan. Pakistan Human Condition Report." Center for Poverty Reduction and Income Distribution in Islamabad.

32. Kingdon, G. and M. Soderbom. 2007. "Education Skills and Labor Market Outcomes: Evidence from Pakistan." Centre for Study of African Economies, Department of Economics.

33. Kingsbury, D., J. Remenyi, J. John and J. Hunt. 2004. "Key Issues in Development."Palgrave Macmillan, New York.

34. Lewin, K.M. 2008. "Why some Education for All and Millennium Development Goals will not be Met: Difficulties with Goals and Targets." Compare, Vol.37, No.6, pp. 599-608. 


\section{Macrothink Institute ${ }^{m !}$}

35. Mahmood, M. , T. Javaid, A. Baig. 1994. "Why Children Do Not Go to School in Pakistan-Some Estimates and Theoretical Framework." The Pakistan Development Review, Vol.33, No.4, pp.1231-1248.

36. National Education Policy, 2009. Government of Pakistan, Ministry of Education, Islamabad. www.moe.gov.pk.

37. Nconco.F. 2006. A comparative study of leadership and management approaches in further education and training colleges. A dissertation submitted in fulfillment for requirement for the degree of doctor of education. Nelson Mandela Metropolitan University.

38. Orazem, P.F. and E.M. King. 2007. "Chapter 55 Schooling in Developing Countries: The Roles of Supply, Demand and Government Policy." Handbook of Developmental Economics, Vol.4, pp.3375-3559.

39. Pakistan Poverty Reduction strategy Paper (PRSP). 2003. IMF Country ReportNo.4/24. International Monitoring Fund Washington, DC.

40. Papagiannis, G.T. , S.J. Klees, R.N. Bichel. 1982. " Towards the Political Economy of Educational Innovation." Economy of Educational Innovation.” Review of Educational Research, Vol.52, No.2, pp.245-290.

41. Qayyum, A., I.Khawaja and A. Hayder. 2008. "Growth Diagnostics in Pakistan." Working paper of Pakistan Institute of Development Economics (PIDE), Islamabad.

42. Qureshi, S. 2004. "Pakistan: Education and Gender Policy for Girls Education: A Lifetime to Development." International Policy Fellowship 2003-2004, Center for Policy Studies.

43. Rosenbaum, Paul R. 2002. Observational Studies (2nd ed.). New York: Springer-Verlag.

44. Rowlands, J. 1995. "Empowerment Examined," Development in Practice, Vol.5 (2): 101-106.

45. Sathar, Z., N. Crook, C. Callum, S. Kazi. 1988. "Women Status and Fertility Change in Pakistan." Population and Development Review, Vol.14, No.3, pp.415-432.

46. Shami, D.P.A. , I. Fazeelat, K.S. Hussain. 2005. "Development of Education in Pakistan." Academy of Educational Planning and Management, ministry of Education, Islamabad.

47. Siddique, R. 2007. "Gender dimensions of Poverty in Pakistan." Paper delivered at Asia and Pacific Forum: Reforming Policies and Institutions for Poverty Reduction.

48. Stanton, E. 2007. "The Human Development Index: A History." Working Paper series, number 127. Political Economy Research Institute, University of Masachus etts, Amherst.

49. Summers,L.H. 1994. "Investing in All the People: Educating Women in Developing Countries: EDI Seminar Paper 45, World Bank, Washington DC.

50. Tansel, A. 2002. "Determinants of School Attainment of Bots and Girls in Turkey: Individual, Household and Community Factors." Economics of Education Review, Vol.21, No.5, pp.455-470.

51. Tembon, M. and Fort, L. 2008. "Girls Education in the $21^{\text {st }}$ century." The International Bank for the Reconstruction and Development. The World Bank, Washington DC. 
52. Turrent, V. and Oketch, M. 2009. "Financing Universal Primary Education: An Analysis of Official Development Assistance in Fragile States." International Journal of Educational Development, Vol.29, No.4, pp.357-365.

53. Watkins, K. 2000. "The Oxfam Education Report.” Oxfam GB in Association with Oxfam International, England.

54. World Bank. 2007. "Higher Education Policy Study.” Volume 1: Strategic Directions for Higher Education in Turkey. Report No. 39679. Human Development Sector Unit Europe and Central Asia Region Document of World Bank. 